\title{
Legal Protection of Solvent Companies from Bankruptcy Abuse in Indonesian Legal System
}

\author{
M. Hadi Shubhan \\ Faculty of Law, \\ Airlangga University, \\ Surabaya, Indonesia
}

Doi: 10.36941/ajis-2020-0031

\section{Abstract}

In bankruptcy legal system in Indonesia, the court can issue bankruptcy verdict without assess a company's solvency condition, whether the company is solvent or insolvent. The provision of this law is very prone to be misused by creditors with bad faith. Insolvency test is able to protect debtors and to prevent the abuse of bankruptcy by malice creditors. This paper aims to analyze the legal protection of solvent companies from bankruptcy abuse in Indonesian legal system. By using normative and juridical approach, the results showed that the insolvency test can be included in the future amendment of Indonesian bankruptcy law. The implementation of insolvency test therefore is not administered outside the bankruptcy proceedings, but still in the respective bankruptcy proceedings. Insolvency test can be implemented by judges based on convincing evidences such as money report made by registered Public Accountant Office. A debtor, with bad faith, should not be eligible to get protection to avoid himself from bankruptcy with the insolvency test, although the debtor has good solvability.

Keywords: business law, solvent, abuse, bankruptcy, Indonesia

\section{Introduction}

In Indonesia, bankruptcy law is a legal instrument designed to function as an instrument for collecting unpaid debts from a debtor who cannot afford and stop paying his debt. It is not as an instrument for resolving unpaid debt due to the reason for insolvent condition of debtor. Such bankruptcy law design cannot be blamed due to the existing law structure and legal culture. However, the design is prone to bankruptcy abuse against a solvent company (Steele, 1999; Lindsey, 1998). The courts are not able to be accused absolutely for declaring insolvency to those companies nor considered right. It cannot be fully accused since judges still adheres to the requirement in the Law 37 of 2004 on Bankruptcy and Suspension of obligation for Payment (hereinafter Bankruptcy Law). According to Article 2 paragraph (1) Indonesia Bankruptcy Law, expressis verbis stipulated for material requirement to submit bankruptcy proceedings. The first is when there is a debt that has matured and collectible, and the second is the minimum presence of two creditors (Juwana, 2005; Linnan, 2006).

The Article 2 paragraph (1) of Indonesia Bankruptcy Law does not require other conditions except those two, excluding debtor's bad solvability (Wahyudi, 2019). This article underlines that judges only use two parameters. Hence, they cannot be accused for upholding the law provision. 
Moreover, the Article 8 paragraph (4) of Indonesia Bankruptcy Law obligates judges to grant respective bankruptcy petitum. Nevertheless, the implementation of Article 2 paragraph (1) Indonesia Bankruptcy Law applies rigidly to all conditions, which can be potentially causing new and more complex problems as well as creating injustice in certain cases, such as bankruptcy cases to very solvent debtors in the previous bankruptcy examples.

For the reason above, the legal protection for solvent companies with good faith is significantly necessary to avoid the abuse of bankruptcy law instrument (Sewu, 2019). The form of the legal protection is the consideration of company's solvability by judges in declaring or rejecting bankruptcy. The solvability consideration can be seen or assessed from insolvency test. However, the solvability consideration should not be a tyranny to hamper the bankruptcy of debtor who obviously has bad faith. Hence, this paper aims to analyze the legal protection of solvent companies from bankruptcy abuse in Indonesian legal system. This paper is divided into several sections. The first part discusses the philosophy of bankruptcy. The second part discusses requirements for bankruptcy in Indonesia, using a quantitative basis as a formula for resolving bankruptcy matters in court. The third section highlights the fundamental forms and basis for legal protection in the bankruptcy legal system in Indonesia.

\section{Principles of Bankruptcy Law in Indonesia}

Literally, the nomenclature of bankruptcy refers to a condition where a debtor has no financial capacity to pay his debts that are due. Bankruptcy as the state or condition of individuals who are unable to pay the debts as they are, or become, due (Black, 1979; Honsberger, 1980). Although a debtor has due and payable debts, it is often the case that the debtor is unable to pay because of his insufficient financial condition. If a debtor is in this condition of inability to pay, the law decides that all his assets by law serve as guarantee of his debts for his creditors. This is stipulated in Article 1131 of Indonesian Civil Code (Little \& Kamarul, 2018; Hartanto, 2015). In this article, it is written that "all of a borrower's assets, whether movable or immovable, existing or will exist in the future, secures all of its obligations under any agreements it enters into". The provision in Article 1131 of this Indonesian Civil Code enshrines the principle of paritas creditorum (Declercq, 2002; Milo \& Smits, 2000; Wessels, 2007). To exercise the stipulation of Article 1131 of Indonesian Civil Code, it has to be ensured that all creditors are entitled to be compensated with the debtor's assets without any exception (Hartanto, 2017).

The principle in Article 1131 of this Indonesian Civil Code cannot be implemented if the asset condition of a debtor is less in number than his due and payable debts, while all creditors compete one another to collect the debts by using legitimate or illegitimate procedures based on the law. If creditors compete each other to collect their credit repayment from debtor but the debtor's debts are greater than his assets, the first creditors will receive his credit repayment. In contrast, the later creditors will not receive even a small part of the assets because all debtor's assets have run out to pay the first creditor. This condition of preceding one another will definitely induce unfairness for creditors who do not receive anything as their credit repayment, whereas Article 1131 of Indonesian Civil Code firmly assures creditors' credit repayment with the debtor's assets by law.

The bankruptcy law stipulates a rule that aims to distribute debtor's property to all his creditors by performing general confiscation to all debtor's assets and dividing them among all his creditors in accordance to their debtor's loan proportions. This bankruptcy provision is the implementation continuation of Article 1131 juncto 1132 of Indonesian Civil Code. It is the realization of the principle of paritas creditorum and the principle of pari passu pro rata parte (see also for comparison, Wright, 2011; Buchheit, \& Pam, 2004).

Basically, bankruptcy constitutes an institution that offers a solution against any party whenever a debtor in a certain condition stops payment or is unable to pay. The bankruptcy institution prevents from or avoids two things, both of which are unjust actions which can disadvantage all parties. The two are (1) to avoid mass execution by debitor or creditor, and (2) to prevent from 
accuracy of dishonesty by the debtor (Hartono, 1999). Furthermore, Hartono (1999) stated that the aforementioned possibilities inflict the following harms to many people in conditions where (1) creditors do not participate in unlawful execution, (2) debtors cannot combat unlawful and unfair execution, (3) third party acts in good faith, and (4) creditors act in good faith. Bankruptcy institution is further implementation of Article 1131 ammended by Article 1132 of Indonesian Civil Code about the principle of paritas creditorum and the principle of pari passu pro rata parte. The Article 1131 of Indonesian Civil Code stipulates that "all of a borrower's assets, whether movable or immovable, existing or will exist in the future, secures all of its obligations under any agreements that enters into".

The formulation of Article 1131 of the Indonesian Civil Code shows that all conducts done by legal person in the sphere of civil law especially property law field will bring consequences to his property, increasing the number of his property or reducing the number of his property. Thus, all the properties owned by the legal person are always in dynamic situation and change from time to time. As a result, all established or binding agreements can either proliferate or diminish the property of the legal person. Nonetheless, if a legal person has more than one obligation to fulfill towards more than one legal person who have the rights to the obligation fulfillment in the relation of the property law, the stipulation of Article 1132 of Indonesian Civil Code states that "the assets shall serve as joint guarantees for his creditors; the proceeds thereof shall be divided among the creditor in proportion to their loan, unless there exists a legal order of priority among the creditors."

The Article 1132 of Indonesian Civil Code is the crystallization of the principle of pari passu pro rata parte. In the context of this Article 1132, all stakeholders have the rights of obligation fulfillment of the assets of the person held liable/debtor with the following principles:

1. pari passu, meaning that all creditors are jointly together obtaining a settlement without precedence;

2. pro rata parte, meaning that the proporsional division is based on the size of the individual creditor's receiveable compared to overall creditors' claims upon the whole assets of the debtor.

According to the general principles of paritas creditorum and pari passu prorata parte inherent in both articles, the bankruptcy regulation is a further, technical, and operational clause. Bankruptcy institution has two fundamental functions. Firstly, bankruptcy as institution provides guarantee that debtor shall never perform dishonestly, and shall be responsible to all creditors. Secondly, bankruptcy as institution also provides creditors with protection against possible mass execution by creditor. Therefore, the presence of ordinance bankruptcy as both an institution and specific legal pursuits constitutes a series of concept which consistently comply with ordinance as stipulated in articles 1131 and 1132 of the civil code.

To avoid the seizure and illegal claims of debtor's property, it is necessary to perform asset freezing (general confiscation) on the debtor's assets, all transactions related to the assets can be stopped. The form of the asset freezing can be conducted with bankruptcy instrument. If a debtor is declared bankrupt, all his assets are in the condition of general confiscation (public attachment/gerechtelijke beslag). Article 1 paragraph (1) of Indonesian Bankruptcy Law mentions that "bankruptcy shall mean general confiscation of all assets of a bankrupt debtor that will be managed and liquidated by a Curator under the supervision of supervisory judge as provided for herein". The Article 1 paragraph (1) of Indonesian Bankruptcy Law emphasizes that the bankruptcy aims to conduct general confiscation over a bankrupt debtor's assets in order to secure them from seizure or precedence act of his creditors. When a debtor's assets are declared in the general confiscation state, all lawful or unlawful attempts on the debtor's assets must be ceased, and the former confiscation before bankruptcy verdict must be raised again. This philosophy shows the interest of debtors have to be protected towards efforts that can disadvantage creditors by paritas. General confiscation occurs for the law sake when bankruptcy verdict is declared upon debtor. So, it is no longer necessary to carry out general confiscation because there has been public attachment legally over the bankrupt debtor's assets. 


\section{Requirement for Bankruptcy in Indonesia}

The requirement for bankruptcy petition is $2+1$. It means that there are two material requirements to be fulfilled in order to file bankruptcy petition. Firstly, the debtor has one debt that is due and payable in which the debt is not fully paid. Secondly, the debtor must have at least two creditors (see in Astiti, 2016, for the discussion about criminal liability of curators). The '+1' means that those material requirements can be simply proved. This $2+1$ requirement for filing bankruptcy petition is written expressis verbis in Article 2 paragraph (1) junto Article 8 paragraph (4) of Indonesian bankruptcy Law. The Article 2 paragraph (1) states that a debtor having two or more creditors and failing to pay at least one debt which has matured and became payable, shall be declared bankrupt through a Court decision, either at his own petition or at the request of one or more of his creditors. Additionally, the Article 8 paragraph (4) of Indonesian Bankruptcy Law stipulates that the petition for declaration of bankruptcy shall be granted if there are facts or circumstances summarily proving that the conditions for a declaration of bankruptcy as referred to in Article 2 paragraph (1) have been met.

The filing bankruptcy petition is therefore must meet and to only meet the $2+1$ condition. The words 'must meet' mean that the petitioner must be able to prove that the debtor has one debt that falls due and payable, and does not pay off only one of his debts, and as long as there are at least two creditors, which can be confirmed in a simple way. In addition, what is meant by 'only meet' is there is no other condition to be fulfilled other than this $2+1$. This requirement $2+1$ of filing a bankruptcy petition has both advantage and disadvantage. The advantage of this $2+1$ requirement is that bankruptcy instrument is expected to provide certain and fair exit mechanism towards the solution of debtor's debts to creditors. Moreover, the existence of this requirement makes filing bankruptcy petition become easy, simple, and not complicated. This advantage can be perceived by debtor who is experiencing financial distress, irrespective of his willingness has to resolve his problems, and bankruptcy is the appropriate instrument. With this requirement of $2+1$, filing bankruptcy petition will occur to be accessible and fast without other requirements/conditions.

Another benefit of this requirement of $2+1$ is to deal with debtors with bad faith who intentionally escape from his responsibilities to pay his debts. The existence of the $2+1$ requirement paves a way for creditors to resolve their repayment with their debtor who act in bad faith by filing a bankruptcy petition against the debtor. Creditor does not need to prolong and complicate bankruptcy petition filing against his debtors. In this regard, bankruptcy is the application of debt pooling. Debt collection principle has a meaning of revenge concept from creditor(s) to bankrupt debtor by filing his claim towards debtor or debtor's assets (Shubhan, 2019a). In the past, debt collection is manifested in form of slavery, mutilation of debtor's body, and even debtor's dismemberment, whereas the modern principle of bankruptcy law creditor manifests itself in form of asset liquidation (Yuhassarie, 2005). Harnowo (2005) asserted that bankruptcy can be used as forcing mechanism and extortion. Furthermore, bankruptcy law is required as collective proceeding, meaning that creditors will compete one another to claim debtor's assets for their own interest without the existance of bankruptcy law. Thus, bankruptcy law overcomes what is called collective action problem that resulted from creditors' individual interest. In bankruptcy law, there is a mechanism where creditors can decide together whether a debtor's company can continue to operate, and can force minority creditors to follow the skim because voting procedure (Yuhassarie, 2005).

However, the requirement of 'must and 'only' $2+1$ also have some disadvantages for debtor's firm or individual who has good solvability and faith, instead of the creditors or other stakeholders who act with bad faith to abuse bankruptcy. Debtor with good faith will be difficult to face bankruptcy petition against himself if the requirement of filing bankruptcy is only this $2+1$. In some cases, some debtors who do not pay his debt actually do not have bad faith as it is a reverse situation for the creditor with bad faith In this case, solvent companies have to face the bankruptcy threat that is not supposed to be filed petitions against him. 


\section{Forms of Legal Protection in Bankruptcy Law}

The requirement to file a bankruptcy petition is the aforementioned $2+1$ requirement. Filing petition only requires debts that have fallen due and payable, where the debtor cannot pay one of his debts and the existence of at least two creditors. Both requirements can be proved in a simplistic way. This easy requirement of filing bankruptcy petition has both advantages and harms especially for solvent debtors who act in good faith from the abuse of bankruptcy instrument. One of the harms from this easy bankruptcy petition filing is that it can jeopardize debtors with good solvability and faith, yet they have civil law disputes with creditors. Therefore, there needs to be a legal protection for debtors, whether it is individual or law institution. Application of insolvency test before or during bankruptcy petition investigation is a form of legal protection for debtors with good solvability and faith before or during bankruptcy petition. Insolvency test is a debtor's capability test in order to pay the debts, consisting of company's cash flow test and balance sheet. Cash flow test checks the amount of cash in and cash out and relates it with the ability of a company to pay some of its debt obligations. If the cash flow test's result is negative, the company belongs to insolvent company category. Conversely, if a positive result is obtained in cash flow test, the company is categorized as solvent company.

Balance sheet test compares the total assets and total liabilities in which if the asset value is less than liabilities, the company is considered insolvent. On the other hand, if the standing liabilities are less than total asset of the company, the company is considered solvent company. The legal protection is granted to a solvent company if it is facing bad-faith creditors who want to abuse bankruptcy instrument for his own benefits or others'., it is significantly to protect the solvent company with good faith. On the other hand, debtors who act in bad faith should not be protected from bankruptcy although they are solvent companies. Bankruptcy declared to solvent debtor who has bad faith is still relevant. This is based on the rationale that it is unfair to protect debtor with bad faith from bankruptcy that is happening to him.

The relevance of this insolvency test is related to the purpose of the bankruptcy instrument that is explained previously. The fundamental purpose of bankruptcy is the management of collection and distribution of bankrupt asset for paying debtor's debt obligation to his creditors. To collect bankrupt assets, all debtor's assets will be under confiscation condition (Shubhan, 2019b). If debtor's assets are not under such condition, the possibility to trade debtor's assets and to do partial confiscation like conservatoir beslag (CB) is widely open. By being declared bankrupt, all assets by law are called as general confiscation.

A company that has larger amount of assets than its standing liabilities has no relevance with debtor's asset dispute among creditors. It is because creditors who come later will still receive the fulfilment of his repayment form debtor's assets. If debtor's assets are more than his liabilities, the Article no 1131, 1132, 1133, and so on so forth of Indonesian Civil Law is still guaranteed its fulfilment. The fulfilment can come in two ways. Firstly, the debtor voluntarily pays his debts with the assets he has, or the second alternative is that creditors can sue debtor who involuntarily pay his debts for breach of contract to the court so that debtor's assets will be executed for the fulfilment of the standing debts.

Bankruptcy is genuinely a fulfilment guarantee and implementation of Articles 1131, 1132, and 1133 of the Indonesian Civil Law, especially in the condition where debtor's assets are not sufficient to pay his debts. Meanwhile, if the debtor's assets are bigger than his debts, the Articles 1131, 1132, and 1133 of the Indonesian Civil Law can be fulfilled without having to go through bankruptcy. This means bankruptcy instrument will not have its urgency anymore if the debtor's assets exceed his debts or the debtor is solvent. If the bankruptcy instrument no longer has its urgency and the debtor is considered solvent, the debtor needs to get legal protection from creditors who use bankruptcy instrument with bad faith or abuse the instrument.

Insolvency test instrument is the protection given to solvent debtors from creditors who act in bad faith or abuse the bankruptcy instrument. With insolvency test instrument, debtors who pass the test cannot be declared bankrupt. Therefore, if companies that have very bright business prospect 
and good payment ability are declared bankrupt, it will disadvantage many stakeholders. Perhaps, only a handful of bad-faith creditors are put in more favorable position, but the majority of stakeholders including debtor, other creditors, labors, good/service providers, consumers and other related stakeholders will be jeopardized with the debtor's bankruptcy. It is the situation where law must provide fairness or justice to major stakeholders. However, insolvency test can be applied to all bankruptcy petition. For instance, debtors who have bad faith to not pay his debts are not eligible for getting law protection from bankruptcy although they have good solvability. This is because law has to be blind. Law must be enforced regardless individuals and individual's interests. Debts are still debts that have to be paid though breach of contract mechanism or bankruptcy petition.

\section{Legal Foundation of Protection Law in Bankruptcy Institutionalization}

Insolvency test can be considered to in the future to protect solvent companies that act in good faith. It is intended to avoid the abuse of bankruptcy institution to benefit certain people and to avoid individual or group who intentionally uses bankruptcy institution to benefit himself by disadvantaging others. The application of this insolvency test functions as a facility to protect debtors with good faith cannot be treated the same way for all bankruptcy petitions (Tobing, 2018). Debtors with good solvability who act in bad faith since beginning to neglect his debts are not supposed to be protected from the bankruptcy striking them. Hence, the role of laws is to determine which solvent debtors that are and are not eligible for the legal protection (Harahap, 2018).

In order to implement protection for debtor who has solvability, judges can consider the solvability of bankrupt debtor before declaring the debtor bankrupt. Law No. 37 of 2004 on Bankruptcy and Suspension of Debt does not regulate insolvency test. It means judges do not declare bankrupt to debtors, mutatis mutandis, although they have fulfilled the requirement of due and payable debts as well as the presence of two or more creditors. Judges can consider other conditions outside the requirements regulated in Article 2 paragraph (1) of Indonesian Bankruptcy Law. The other consideration or condition is the solvability and good faith of debtors over the inability to pay debts. If judges are convinced with evidence stating that debtor are in solvent condition and his inability is due to good faith, judges can decline to declare the debtor bankrupt.

Judges' consideration of other conditions that are regulated in Article 2 paragraph (1) of Indonesian Bankruptcy Law is based on Article 8 paragraph (6) letter a of Indonesian Bankruptcy Law. The Article 8 paragraph (6) letter a of Indonesian Bankruptcy Law states that the court decision as referred to in paragraph (5) shall contain particular article(s) of the relevant law or regulation and/or unwritten legal source that is used as the basis for hearing the petition, while unwritten legal sources include ethics, equity, fairness, and legal doctrine.

\section{Conclusion}

The form of legal protection for debtors who have good solvability and faith from the bankruptcy abuse by creditors with bad faith is by considering financial solvability level, where if the financial solvability of a debtor is good, the court can reject to declare bankrupt. The stipulation of insolvency test can be added to the amendment of Law No. 37 of 2004 on the Bankruptcy and Suspension of Payment by considering the interests of both debtors and creditors. As long as there has not been any change of Law 37/2004, judges can provide protection to solvent debtors from bankruptcy instrument abuse by debtors who act in bad faith by using the principle of appropriateness, equity, and fairness.

The application of insolvency test in the future has to consider some aspects. First, insolvency test is not required for all bankruptcy petition, but only for debtors who act in good. Second, insolvency test is considered by judges in assessing bankruptcy petition. So, it is not necessary to conduct another investigation outside the bankruptcy proceedings. Third, there is a need for supporting evidences of debtor's solvability in form of the audit result from the registered office of public accountant. 


\section{References}

Astiti, S. H. (2016). Pertanggungjawaban Pidana Kurator Berdasarkan Prinsip Independensi Menurut Hukum Kepailitan. Jurnal Hukum dan Peradilan, 5(2), 277-298.

Black, H.C. (1979). Black's Law Dictionary. West Publishing Co..

Buchheit, L. C., \& Pam, J. S. (2004). The pari passu clause in sovereign debt instruments. Emory LJ, 53, 869.

Declercq, P. J. (2002). Netherlands insolvency law: the Netherlands Bankruptcy Act and the most important legal concepts. Lawrence Erlbaum Associates.

Harahap, P. (2018). Eksekutabilitas putusan arbitrase oleh lembaga peradilan/the executability of arbitration award by judicial institutions. Jurnal Hukum dan Peradilan, 7(1), 127-150.

Harnowo, T. (2005). A Brief Note on Bankruptcy Law, In Valerie Selvie (Ed.). Analysis of Bankruptcy Decisions at the Jakarta Commercial Court. Jakarta: Faculty of Law, Atmajaya Catholic University.

Hartanto, J. A. (2015). The Legal Development of Guarantee in Indonesia. JL Pol'y E Globalization, 36, 57.

Hartanto, J. A. (2017). Indonesian Law Development on Housing Collateral. Mediterranean Journal of Social Sciences, 8(6), 109-115.

Hartono, S.R. (1999). Civil Laws as Foundation For Modern Laws on Bankruptcy. Jurnal Hukum Bisnis 7(1), 1-15.

Honsberger, J. (1980). Failure to Pay One's Debts Generally As They Become Due: The Experience of France and Canada. Am. Bankr. LJ, 54, 153.

Juwana, H. (2005). Reform of Economic Laws and its Effects on the Post-crisis Indonesian Economy. The Developing Economies, 43(1), 72-90.

Lindsey, T. (1998). The IMF and Insolvency Law Reform in Indonesia. Bulletin of Indonesian Economic Studies, 34(3), 119-124.

Linnan, D. K. (2006). Insolvency Law and Institutions in Indonesia. In R. Tomasic (Ed.), Insolvency Law in East Asia. Ashgate Publishing, Ltd.

Little, P., \& Kamarul, B. K. (2018). Company Law in Indonesia. In R. Tomasic (Ed.), Company Law in East Asia. Dartmouth Pub Co

Milo, M., \& Smits, J. (200o). Trusts in mixed legal systems: a challenge to comparative trust law. European Review of Private Law, 8(3), 421-426.

Sewu, P. L. S. (2019). Good Faith as a Key Principle of Business Ethics to Franchise Agreement and Development in Indonesia. Journal of Legal, Ethical and Regulatory Issues 22(1).

Shubhan, M. H. (2019a). Charging Director of Company with Personal Bankruptcy for Company Mismanagement. Jurnal Hukum dan Peradilan, 8(3), 353-370.

Shubhan, M. H. (2019b). Misuse of Bankruptcy Petitions by Creditors: The Case of Indonesia. International Journal of Innovation, Creativity and Change 10(6), 195-207.

Steele, S. (1999). The new law on bankruptcy in Indonesia: towards a modern corporate bankruptcy regime. Melb. UL Rev., 23, 144 .

Tobing, C. N. (2018). Menggagas pengadilan hubungan industrial dalam bingkai ius constituendum sebagai upaya perwujudan kepastian hukum dan keadilan/Initiating an industrial relations court in the framework of ius constituendum as an effort to realize legal certainty and justice. Jurnal Hukum dan Peradilan, 7(2), $297-326$.

Wahyudi, F. (2019). Quo Vadis of Banckrupty Settlement and Pkpu Laws on Sharia Banking. Jurnal Hukum dan Peradilan, 8(1), 1-20.

Wessels, B. (2007). Europe deserves a new approach to insolvency proceedings. European Company law, 4(6), 253259.

Wright, M. L. (2011). The Pari Passu clause in sovereign bond contracts: Evolution or intelligent design. Hofstra L. Rev., 40, 103.

Yuhassarie, E. (2005). Rethinking Indonesia's Bankruptcy Law, In Emmy Yuhassarie (ed.), Bankruptcy Law and Its Development. Jakarta: Pusat Pengkajian Hukum. 